\title{
Right to a Fair Trail in the Prespective of European Convention on Human Rights
}

\author{
Agron Bajri \\ European University of Tirana, Faculty of Justice, PhD Candidate \\ Email:agronbajri@gmail.com
}

Doi:10.5901/mjss.2014.v5n27p283

\begin{abstract}
The right to a fair trial is a norm of international human rights law designed to protect individuals from the unlawful and arbitrary curtailment or deprivation of other basic rights and freedoms, the most prominent of which are the right to life and liberty of the person. Also Article 6 guarantees the right to a fair trial which is of fundamental importance in a democratic society, occupying a central place in the Convention system. Their object and purpose enshrines the principle of the rule of law, upon which such a society is based and built, as well as reflects part of the common heritage of the States parties to the Convention, according to the Preamble of the Convention. Article 6 is the provision of the Convention most frequently invoked by applicants to the European Court of Human Rights (the Court). The right to a fair trial might seem an unimpeachable example or "paradigm case" of what we mean by a "right" and certainly it is so widely believed that people have such a right that to claim they generally do not strikes one initially as absurd. The main purpose of this paper is to answer the question of what are the basic legal standards that should be used in evaluating the fairness of a trial. The second is how a trial observation mission should be prepared and carried out in practice.
\end{abstract}

Keywords: trial; rights; human; duties; Penal Code;

\section{Introduction}

The right to a fair trial is commonly considered so central to our system of justice and so much a part of our legal heritage that to deny that people in general have any such right might seem tantamount to impugning our legal traditions as a whole. The right to a fair trial might seem an unimpeachable example or "paradigm case" of what we mean by a "right" and certainly it is so widely believed that people have such a right that to claim they generally do not strikes one initially as absurd. I hope nonetheless to present reasons for thinking that people do not in fact generally have a right to a fair trial. Here as elsewhere something similar is true instead, and I hope at least briefly to suggest a proper approach to justification for fair trials as well as to dispute the justification most commonly offered.

The fundamental importance of this right is illustrated not only by the extensive body of interpretation it has generated but, most recently, by a proposal to include it in the non derogable rights provided for in Article 4(2) of the ICCPR ${ }^{1}$. The right to a fair trial is applicable to both the determination of an individual's rights and duties in a suit at law and with respect to the determination of any criminal charge against him or her. The term "suit at law" refers to various types of court proceedings-including administrative proceedings, for example-because the concept of a suit at law has been interpreted as hinging on the nature of the right involved rather than the status of one of the parties ${ }^{2}$. For the purposes of this guide only proceedings involving criminal charges will be considered since non-governmental organizations (NGOs) typically monitor criminal trials or, more precisely, criminal trials involving "political" offenses ${ }^{3}$.

\footnotetext{
1 See Draft Third Optional Protocol to the ICCPR, Aiming at Guaranteeing Under All Circumstances the Right to a Fair Trial and a Remedy, Annex I, in: "The Administration of Justice and the Human Rights of Detainees, The Right to a Fair Trial: Current Recognition and Measures Necessary for Its Strengthening," Final Report, Commission on Human Rights, Sub-Commission on Prevention of Discrimination and Protection of Minorities, 46th Session, E/CN.4/Sub.2/1994/24, June 3, 1994 [hereinafter The Final Report], at 59-62. (http://www.unhchr.ch/Huridocda/Huridoca.nsf/TestFrame/d8925328e178f8748025673d00599b81?Opendocume $n t)$.

2 See Dominic McGoldrick, The Human Rights Committee, Its Role in the Development of the International Covenant on Civil and Political Rights (Clarendon Press, Oxford: 1994), at 415.

3 There is, at present, no positive definition of what constitutes a "political offense" and therefore little guidance on which proceedings may be deemed "political" in nature. In this context it should be noted that trial observation is a very useful mechanism for the prevention of human rights abuses but one that, necessarily, depends on the willingness of a government to conduct a trial in the first place. As is well known, in many areas of the world individuals are still being arrested, imprisoned and executed without any trial at all.
} 
Due to the specifics of each individual case and the interests of monitoring organizations, a detailed rendition of trial observation aims is not feasible. The key general goals may be summarized as follows:

- to make known to the court, the authorities of the country and to the general public

- the interest in and concern for the trial in question;

to encourage a court to give the accused a fair trial. The impact of an observer's presence in a courtroom cannot be evaluated with mathematical precision. However, both observers and defense attorneys have pointed out that a monitor's presence often changes the atmosphere in the courtroom and facilitates defense by, inter alia, making the court more cognizant of the defense's arguments, encouraging defense counsel and the defendant to be more forceful in contesting the prosecution's claims, in attracting media attention to the trial, etc;

- to obtain more information about the conduct of the trial, the nature of the case against the accused and the legislation under which s/he is being tried; and to collect general background information about the political and legal circumstances leading to the trial and possibly affecting its outcome ${ }^{4}$.

In the broader sense, trial monitoring consists not only of an observer's physical presence in the courtroom during at least part of the proceedings but, just as importantly, of the duty promptly to prepare a report for the organization he or she represents, with conclusions on the fairness of the trial observed. The publicity which this report receives may serve in the short term to enhance a defendant's chances of having his/her case fairly reviewed on appeal. The lasting aim is to inform the government and the general public of possible irregularities in criminal procedure and to prompt action to bring practice into line with international human rights standards. The basic criteria according to which the fairness of a trial may be assessed is the first issue that will be dealt with in this review. The second is how a trial observation mission is typically carried out.

\section{Basic Fair Trial Criteria}

The standards against which a trial is to be assessed in terms of fairness are numerous, complex, and constantly evolving. They may constitute binding obligations that are included in human rights treaties to which the state is a party. But, they may also be found in documents which, though not formally binding, can be taken to express the direction in which the law is evolving ${ }^{5}$. In order to avoid possible challenges to the legal nature of the standards employed in evaluating the fairness of a trial, monitors should refer to norms of undisputedly legal origin.

These are:1. the laws of the country in which the trial is being held; 2 . the human rights treaties to which that country is a party, and 3. norms of customary international law ${ }^{6}$.

Before observing a trial, a monitor should read relevant materials pertaining to domestic legislation. Due to the various legal systems and legal orders involved, as well as the differing stages of their development, it is not possible to devise a comprehensive list of essential texts. A minimum list would comprise: i) a state's Constitution, especially its provisions on human rights and the judicial system; ii) its Criminal Code and Code of Criminal Procedure; statutes on the establishment and jurisdiction of the courts and on the public prosecutor's office, and iii) landmark court decisions pertaining to human rights, particularly in common law countries. The aim of an observer at this level of examination is to assess whether the applicable provisions of domestic law guaranteeing a fair trial have been implemented and, if so, to what extent. It is well known that while constitutions and statutes generally provide for some measure of fairness in criminal proceedings, implementation by the courts is often not adequate.

Before undertaking a trial observation mission, a monitor should find out to which human rights treaties the respective state is a party. The most important of these is the ICCPR, which contains several relevant articles in assessing the fairness of a trial?.

${ }^{4}$ See International Commission of Jurists (ICJ), "Guidelines for ICJ Observers to Trials" (ICJ, Geneva: 1978).

${ }^{5}$ Non-binding documents of relevance to the conduct of criminal proceedings and to ascertaining fair trial standards include: the Basic Principles for the Treatment of Prisoners, UN General Assembly resolution 45/111, December 14, 1990 [hereinafter Basic Principles on Prisoners]; Standard Minimum Rules for the Treatment of Prisoners, UN Economic and Social Council resolution 663 C (XXIV), July 31, 1957 and resolution 2076 (LXII), May 13, 1977 [hereinafter Standard Minimum Rules];

6 The provisions of the Universal Declaration of Human Rights, (UN General Assembly resolution 217A (III), December 10, 1948 [hereinafter UDHR]), are for the most part considered declarative of customary international law and may be of paramount importance if a state has not ratified or acceded to the ICCPR, the Convention against Torture and Other Cruel, Inhuman or Degrading Treatment or Punishment, (UN General Assembly resolution 39/46, December 10, 1984, entered into force June 26, 1987 [hereinafter Torture Convention]), or any regional human rights instrument.

7 The web site of the UN High Commissioner for Human Rights has a list of those nations that have ratified the ICCPR at http://www.un.org/Depts/Treaty/final/ts2/newfiles/part_boo/iv_boo/iv_4.html. Depending on the regional human rights instrument(s) that a 
The right to a fair trial on a criminal charge is considered to start running not "only upon the formal lodging of a charge but rather on the date on which State activities substantially affect the situation of the person concerned"8.

This could obviously coincide with the moment of arrest, depending on the circumstances of the case. Fair trial guarantees must be observed from the moment the investigation against the accused commences until the criminal proceedings, including any appeal, have been completed. The distinction between pretrial procedures, the actual trial and post trial procedures is sometimes blurred in fact, and the violation of rights during one stage may well have an effect on another stage. However the most relevant articles of the ICCPR can be loosely divided into those three categories and the separation is sometimes helpful for the purposes of identifying which issues will be of particular interest during different time periods of the trial process.

\subsection{The right to a fair trial under Article 6 of the European Convention for Human Rights}

Article 6 of the European Convention for Human Rights (the Convention) provides:

1. In the determination of his civil rights and obligations or of any criminal charge against him, everyone is entitled to a fair and public hearing within a reasonable time by an independent and impartial tribunal established by law. Judgment shall be pronounced publicly but the press and public may be excluded from all or part of the trial in the interests of morals, public order or national security in a democratic society, where the interests of juveniles or the protection of the private life of the parties so require, or to the extent strictly necessary in the opinion of the court in special circumstances where publicity would prejudice the interests of justice.

2. Everyone charged with a criminal offence shall be presumed innocent until proved guilty according to law.

3. Everyone charged with a criminal offence has the following minimum rights:

(a) to be informed promptly, in a language which he understands and in detail, of the nature and cause of the accusation against him;

(b) to have adequate time and facilities for the preparation of his defense;

(c) to defend himself in person or through legal assistance of his own choosing or, if he has not sufficient means to pay for legal assistance, to be given it free when the interests of justice so require;

(d) to examine or have examined witnesses against him and to obtain the attendance and examination of witnesses on his behalf under the same conditions as witnesses against him;

(e) to have the free assistance of an interpreter if he cannot understand or speak the language used in Court.

Article 6 guarantees the right to a fair trial which is of fundamental importance in a democratic society, occupying a central place in the Convention system. Their object and purpose enshrines the principle of the rule of law, upon which such a society is based and built, as well as reflects part of the common heritage of the States parties to the Convention, according to the Preamble of the Convention. Article 6 is the provision of the Convention most frequently invoked by applicants to the European Court of Human Rights (the Court) ${ }^{9}$.

As with other provisions of the Convention, many of the terms used in Article 6(1) bear "autonomous" meaning and require interpretation which may differ from that given by the domestic law or the national authorities. Hence, the right to a fair hearing contained in Article 6 does not apply to all court proceedings at the domestic level. Both concepts used by the Convention, 'determination of criminal charge' and 'determination civil rights and obligations' are autonomous; thus their content may differ from the qualifications given by the national laws.

While Article 6(2) and (3) contain specific provisions setting out additional procedural standards applicable only in respect of those charged with a "criminal" offence, Article 6(1) applies both to "civil" and "criminal" proceedings. It is also important to note that the majority of issues brought to the Court's attention under the "criminal" limb of Article 6 have concerned fairness of procedural acts by various State officials - at the investigation, trial or appeal stage - leading to a person's conviction. However, the issues brought to the Court's attention under the "civil" heading of Article 6 have touched upon three distinct set of problems:

a) lack of access to a court to have a "civil" dispute determined, b) fairness of judicial proceedings where access

state is bound by, the corresponding provisions of such treaties should be taken into account as well. For European states the most important instrument would be the European Convention for the Protection of Human Rights and Fundamental Freedoms, November 5 , 1950 [hereinafter European Convention] (http://www.coe.fr/eng/legaltxt/5e.htm).

${ }^{8}$ Manfred Nowak, U.N. Covenant on Civil and Political Rights, CCPR Commentary (N.P. Engel, Arlington: 1993) [hereinafter Nowak Commentary], at 244.

${ }^{9}$ Article 6 of the European Convention for Human Rights (the Convention). 
to a court was not restricted, $\mathrm{c}$ ) the right to obtain timely execution of a court judgment in case of a favorable outcome of a "civil" dispute.

There is a threshold question for the applicability of Article 6; that is, whether particular legal proceedings qualify as the "determination of civil rights and obligations or a criminal charge". For Article 6 to apply under its "civil" heading, there must first be a dispute ("contestation") over a "right" or "obligation". Secondly, that "right" must have a basis in national law. Furthermore, the dispute in question must determine that "right" in a direct and decisive manner. Finally, that right or obligation must be "civil" in nature. only having passed all the above tests, the Court will embark on examining an applicant's claim that the impugned domestic proceedings were in breach of the requirements of Article 6 of the Convention.

It is obvious that the concept of "civil right and obligations" covers ordinary civil litigation having the predominant features of private law, such as disputes between private individuals relating, for example, to actions in tort, contract, and family law ${ }^{10}$.

It is more difficult, however, to determine whether Article 6(1) should apply also to disputes between individuals and the State concerning rights which, under some systems of law, fall under the public rather than the private law domain.

\section{2 "Criminal charge"}

The notion of a "criminal charge" in Article 6, like the concept of "civil rights and obligations", is regarded by the Court as possessing an autonomous meaning. Cases have frequently arisen where the impugned behavior is characterized by national authorities as a disciplinary offence rather than a criminal offence.

In cases concerning a "criminal" charge within the meaning of Article 6, the protection of this provision starts from the time when a person is charged with a criminal offence. This is not, however, necessarily the moment when formal charges are first made against a person suspected of having committed an offence. Moreover, as the object of Article 6 is to protect a person throughout the criminal process, and since formal charges may not be brought until a fairly advanced stage of an investigation, it is necessary to find a criterion for the opening of criminal proceedings which is independent of the actual development of the procedure in a specific case.

\section{Pre-Trial Rights}

\subsection{The prohibition on arbitrary arrest and detention}

Article 9(1) of the ICCPR10 provides that "everyone has the right to liberty and security of person." The liberty of a person has been interpreted narrowly, to mean freedom of bodily movement, which is interfered with when an individual is confined to a specific space such as a prison or a detention facility. 11 Security has been taken to mean the right to be free from interference with personal integrity by private persons. Under Article 9(1) "No one shall be subjected to arbitrary arrest or detention" and "No one shall be deprived of his liberty except on such grounds and in accordance with such procedure as are established by law"11.

Article 9(2) of the ICCPR provides that "Anyone who is arrested shall be informed, at the time of arrest, of the reasons for his arrest and shall be promptly informed of any charges against him." These provisions have been interpreted to mean that anyone who is arrested must be informed of the general reasons for the arrest "at the time of arrest," while subsequent information, to be furnished "promptly," must contain accusations in the legal sense ${ }^{12}$.

\subsection{The right to legal counsel}

The right to be provided and communicate with counsel is the most scrutinized specific fair trial guarantee in trial observation practice, because it has been demonstrated to be the one that is most often violated. Principle 1 of the Basic

${ }^{10}$ See also European Convention, Article 6.

${ }_{11}$ See also European Convention, supra note 8, Article 5(1); African Charter, supra note 8, Article 6; American Convention, supra note 8, Article 7(1)-(3); and Statute of the International Criminal Court [hereinafter ICC Statute], Article 55(1)(d). The ICC Statute establishes a permanent institution for the purposes of trying persons for the most serious international crimes (including genocide, crimes against humanity and war crimes) where a national legal system has failed to do so. The Statute was approved on July 17, 1998 but will not come into force until 60 nations have ratified. As of February 16, 2000, 94 countries had signed the Statute but only seven countries had ratified it.

12 See also European Convention. 
Principles on Lawyers states that "all persons are entitled to call upon the assistance of a lawyer of their choice to protect and establish their rights and to defend them in all stages of criminal proceedings." This right is particularly relevant in case of pre-trial detention and is discussed in that context in this section.

However the right to counsel is also an important element of the right to adequate facilities for the preparation of a defense and the right to a defense which will be discussed later in this paper ${ }^{13}$.

\subsection{The right to a prompt appearance before a judge to challenge the lawfulness of arrest and detention}

Article 9(3) refers specifically to the rights of a person arrested or detained on a criminal charge, who "shall be brought promptly before a judge or other officer authorized by law to exercise judicial power and shall be entitled to trial within a reasonable time or to release." Promptness has been interpreted by the Human Rights Committee (HRC) to mean that the period of custody, before an individual is brought before a judge or other officer, may not exceed "a few days."

Article 9(3) makes it clear that pre-trial detention "shall not be the general rule" and implicitly provides a detainee with a legitimate claim to release in exchange for bail or some other guarantee of appearance at the trial ${ }^{14}$.

\subsection{The prohibition of torture and the right to humane conditions during pretrial detention}

Article 7 of the ICCPR prohibits torture-or cruel, inhuman or degrading treatment or punishment-and is a norm of customary international law that also belongs to the category of jus cogens.

The definition of torture, which is prohibited by the ICC Statute as a crime against humanity when committed on a widespread or systematic basis, is slightly broader in that Statute than in the Torture Convention. Unlike the Torture Convention, the ICC Statute definition includes acts committed independently of any public official (i.e. by private individuals with private motives) ${ }^{15}$.

\subsection{The prohibition on incommunicado detention}

The HRC has found that incommunicado detention may violate Article 7 of the ICCPR which prohibits torture, inhuman, cruel and degrading treatment ${ }^{16}$.

Principle 19 of the Body of Principles states that a "detained or imprisoned person shall have the right to be visited by and to correspond with, in particular, members of his family and shall be given adequate opportunity to communicate with the outside world, subject to reasonable conditions and restrictions as specified by law or lawful regulations." At a minimum, the right to communicate with the "the outside world" includes the right to communicate with a detainee's family, a lawyer and a doctor.

\section{Substantive Rights Guaranteed under Article 6}

\subsection{The right to access to a court, and equality before a court}

This is one of the rights that does not flow directly from the text of Article 6(1), and which was developed by the Court. It means that an individual must be able to have a matter brought before a court for determination without any improper

${ }^{13}$ The Human Rights Committee has stated that "all persons who are arrested must immediately have access to counsel." (Concluding Observations of the Human Rights Committee, Georgia, UN Doc. CCPR/C/79 Add.75, April 1, 1997 para 27) [hereinafter Concluding Observations of the HRC]. See also the Report of the Special Rapporteur on the Independence of Judges and Lawyers regarding the Mission of the Special Rapporteur.

${ }_{14}$ See also European Convention, Article 5(3); American Convention, Article 7(5); African Commission Resolution, Paragraph 2(C); and ICC Statute, Article 59(2). (3). See further Body of Principlested Kingdom, UN Doc E/CN.4/1998/39/Add.4, March 5, 1998, para 47.

${ }^{15}$ Article 7(2)(e) of the ICC Statute defines torture as "the intentional infliction of severe pain or suffering, whether physical or mental, upon a person in the custody or under the control of the accused; except that torture shall not include pain or suffering arising only from, inherent in or incidental to, lawful sanctions."

${ }^{16}$ See e.g., Human Rights Commission Resolution 1997/38 para 20 holding that "prolonged incommunicado detention may facilitate the perpetration of torture and can in itself constitute a form of cruel, inhuman or degrading treatment." See further, the Report of the Special Rapporteur on Torture, UN Doc E/CN.4/1995/34, para 926(d) and findings of the Inter-American Commission (Report on the Situation of Human Rights in Bolivia, OEA/Ser.L/VII.53, doc rev.2, 1 July 1981 at 41-42) and Inter American Court (Suavez Rosero Case, Ecuador, 12 November 1997). 
legal or practical obstacles being placed in his or her way. As will be seen, this right is not unqualified and takes rather different forms in the civil and criminal spheres.

The right to a court also includes the right to finality of legal proceedings, and the right to claim timely execution of a civil judgment. According to the Court's interpretation, the right to a court is inherent in Article 6(1), the right of access being one aspect. The lack of access to a court may be relied upon by anyone who complains that he or she has not had the possibility to submit a claim to a tribunal having the jurisdiction to examine all questions of fact and law relevant to the dispute before it and to adopt a binding decision The first sentence of Article 14(1) provides that "All persons shall be equal before the courts and tribunals" and has been interpreted to signify that all persons must be granted, without discrimination, the right of equal access to a court. This, on the one hand, means that establishing separate courts for different groups of people based on their race, color, sex,language, religion, political or other opinion, national or social origin, property, birth or other status would be a contravention of Article 14(1). On the other hand, the establishment of certain types of special courts with jurisdiction over all persons belonging to the same category, such as military personnel, remains a thorny issue.

\subsection{The right to a fair hearing}

The right to a fair hearing as provided for in Article 14(1) of the ICCPR encompasses the procedural and other guarantees laid down in paragraphs 2 to 7 of Article 14 and Article 15. However, it is wider in scope, as can be deduced from the wording of Article 14(3) which refers to the concrete rights enumerated as "minimum guarantees." Therefore, it is important to note that despite having fulfilled all the main procedural guarantees laid out in paragraphs 2-7 of Article 14 and the provisions of Article 15, a trial may still not meet the fairness standard envisaged in Article 14(1) ${ }^{17}$.

\subsection{The right to a public hearing}

Article 14(1) of the ICCPR also guarantees the right to a public hearing, as one of the essential elements of the concept of a fair trial. However, it also permits several exceptions to this general rule under specified circumstances. The publicity of a trial includes both the public nature of the hearings-not, it should be stressed, of other stages in the proceedingsand the publicity of the judgement eventually rendered in a case. It is a right belonging to the parties, but also to the general public in a democratic society.

\subsection{The right to a competent, independent and impartial tribunal established by law}

The basic institutional framework enabling the enjoyment of the right to a fair trial is that proceedings in any criminal case (or in a suit at law) are to be conducted by a competent, independent and impartial tribunal established by law [Article 14(1)]. The rationale of this provision is to avoid the arbitrariness and/or bias that would potentially arise if criminal charges were to be decided on by a political body or an administrative agency. A tribunal should be competent and established by law ${ }^{17}$.

\subsection{The right to a presumption of innocence}

According to Article 14(2) of the ICCPR "Everyone charged with a criminal offense shall have the right to be presumed innocent until proved guilty according to law." As a basic component of the right to a fair trial, the presumption of innocence, inter alia, means that the burden of proof in a criminal trial lies on the prosecution and that the accused has the benefit of the doubt ${ }^{18}$.

\subsection{The right to prompt notice of the nature and cause of criminal charges}

In the determination of any criminal charge against him/her everyone shall be entitled, in full equality "to be informed promptly and in detail in a language which he understands of the nature and cause of the charge against him." This duty to inform relates to an exact legal description of the offense ("nature") and of the facts underlying it ("cause") and is thus

${ }_{17}$ See also European Convention, Article 6(1); and ICC Statute, Article 67(1).

${ }_{18}$ See also Article 14(2) of the ICCPR. 
broader than the corresponding rights granted under Article 9(2) of the ICCPR applicable to arrest ${ }^{19}$.

\subsection{The right to adequate time and facilities for the preparation of a defense}

Article 14(3)(b) of the ICCPR provides that in the determination of any criminal charge against him or her everyone is entitled "To have adequate time and facilities for the preparation of his defense and to communicate with counsel of his own choosing". The right to adequate time and facilities for the preparation of a defense applies not only to the defendant but to his or her defense counsel as well78 and is to be observed in all stages of the proceedings ${ }^{20}$.

\subsection{The right to defend oneself in person or through legal counsel}

The right to counsel in the pre-trial stages of a criminal trial, as discussed earlier in this paper, is clearly linked to the right to a defense during trial as set out in Article 14(3)(d) of the ICCPR. The provision states that everyone shall be entitled, in the determination of any criminal charge against him/her "To be tried in his presence, and to defend himself in person or through legal assistance of his own choosing; to be informed, if he does not have legal assistance, of this right; and to have legal assistance assigned to him, in any case where the interests of justice so require, and without payment by him in any such case if he does not have sufficient means to pay for it"21.

\subsection{The right to examine witnesses}

In the determination of any criminal charge against him/her, everyone is entitled "To examine, or have examined, the witnesses against him and to obtain the attendance and examination of witnesses on his behalf under the same conditions as witnesses against him". This right is an essential element of the principle of equality of arms. The terms "to examine, or have examined" should be read as a recognition of the two main systems of criminal justice, the inquisitorial and accusatorial one. It should be noted that, according to the text itself, the defense does not have an unlimited right to obtain the compulsory attendance of witnesses on the defendant's behalf, but only "under the same conditions" as witnesses against him/her ${ }^{22}$.

No such restriction applies to the prosecution. While a court is thereby given a fairly free hand in summoning witnesses, it must do so in keeping with the principle of fairness and equality of arms. This, in turn, mandates that the parties be equally treated with respect to the introduction of evidence by means of interrogation of witnesses.

\subsection{The right to an interpreter}

In the determination of any criminal charge against him/her everyone is entitled "To have the free assistance of an interpreter if he cannot understand or speak the language used in court" [Article 14(3)(f)]. The right to an interpreter applies equally to nationals and aliens, but cannot be demanded by a person who is sufficiently proficient in the language of the court. When granted, the right to the assistance of an interpreter is free and can in no way be restricted by seeking payment from the defendant upon conviction.

\subsection{The prohibition on self-incrimination}

In the determination of any criminal charge against him/her, everyone is entitled "Not to be compelled to testify against himself or to confess guilt" [Article 14(3)(g)]. This provision aims to prohibit any form of coercion, whether direct or indirect, physical or mental, and whether before or during the trial, that could be used to force the accused to testify against him/herself or to confess guilt.

\section{Conclusion}

The main difference of the requirement of "fairness" from all the other elements of Article 6 is that it covers proceedings

${ }^{19}$ Article 9(2) of the ICCPR.

20 See also European Convention, Article 6(3).

${ }^{21}$ See also Article 14(3)(d) of the ICCPR.

${ }^{22}$ See also Article 14(3)(e) of the ICCPR. 
as a whole, and the question whether a person has had a "fair" trial is looked at by way of cumulative analysis of all the stages, not merely of a particular incident or procedural defect; as a result, defects at one level may be put right at a later stage. The notion of "fairness" is also autonomous from the way the domestic procedure construes a breach of the relevant rules and codes with the result that a procedural defect amounting to a violation of the domestic procedure even a flagrant one - may not in itself result in an "unfair" trial, and, vice-versa, a violation under Article 6 can be found even where the domestic law was complied with.

An examination of the customary international law status of trial observation is outside the scope of this review. However, the practice of sending and receiving trial observers is today so widespread and accepted that it may already constitute a norm of customary international law. The rapid development of the institution of trial observation over the past several decades can be attributed largely to the knowledge and integrity of the individuals who have served as observers. In order for this method of human rights monitoring to expand further, the high standards achieved so far must be maintained and continuously refined. This, among other things, means that the monitors themselves should increasingly be individuals familiar with the intricacies of domestic and international fair trial standards. In practice, they should bring to the performance of their task the very qualities they monitor: fairness and humanity.

\section{References}

Dominic McGoldrick, (1994)The Human Rights Committee, Its Role in the Development of the International Covenant on Civil and Political Rights, Clarendon Press, Oxford.

Manfred Nowak, (1993) U.N. Covenant on Civil and Political Rights, CCPR Commentary (N.P. Engel, Arlington) [hereinafter Nowak Commentary].

Draft Third Optional Protocol to the ICCPR, Aiming at Guaranteeing Under All Circumstances the Right to a Fair Trial and a Remedy, Annex I, in: "The Administration of Justice and the Human Rights of Detainees, The Right to a Fair Trial: Current Recognition and Measures Necessary for Its Strengthening," Final Report, Commission on Human Rights, Sub-Commission on Prevention of Discrimination and Protection of Minorities, 46th Session, E/CN.4/Sub.2/1994/24, June 3, 1994 [hereinafter The Final Report], at 59-62. (http://www.unhchr.ch/Huridocda/Huridoca.nsf/TestFrame/d8925328e178f8748025673d00599b81?Opendocument).

International Commission of Jurists (ICJ), "Guidelines for ICJ Observers to Trials" (ICJ, Geneva: 1978).

Non-binding documents of relevance to the conduct of criminal proceedings and to ascertaining fair trial standards include: the Basic Principles for the Treatment of Prisoners, UN General Assembly resolution 45/111, December 14, 1990 [hereinafter Basic Principles on Prisoners]; Standard Minimum Rules for the Treatment of Prisoners, UN Economic and Social Council resolution 663 C (XXIV), July 31, 1957 and resolution 2076 (LXII), May 13, 1977 [hereinafter Standard Minimum Rules].

Body of Principlested Kingdom, UN Doc E/CN.4/1998/39/Add.4, March 5, 1998.

Human Rights Commission Resolution 1997/38 para 20 holding that "prolonged incommunicado detention may facilitate the perpetration of torture and can in itself constitute a form of cruel, inhuman or degrading treatment." See further, the Report of the Special Rapporteur on Torture, UN Doc E/CN.4/1995/34, para 926(d) and findings of the Inter-American Commission (Report on the Situation of Human Rights in Bolivia, OEA/Ser.L/V/II.53, doc rev.2, 1 July 1981 at 41-42) and Inter American Court (Suavez Rosero Case, Ecuador, 12 November 1997). 